\title{
The influence of small town context on access to external knowledge
}

Rahel Meili

The relative lack of variety and density of people, companies and knowledge institutions in small towns compel companies to seek new knowledge beyond their location. However, there is only scant research explaining the local characteristics that influence companies' ability to access external knowledge. In this article, the focus lies on the obstacles and opportunities that arise due to companies' location in small towns and that emerge when they seek to access external knowledge sources. A multiple case study design with qualitative interview data from five multinational high-tech companies in small towns in the eastern part of Switzerland is used. Also, a theoretical replication of the case study by investigating two single domestic high-tech companies was conducted. The results show that a thin labour market, a lack of urban amenities and the availability of transportation connections to bigger cities are most important for accessing the knowledge of new employees, collaborating with universities and for attending workshops or conferences. On the whole, multinational companies in small towns face the same obstacles and opportunities as single domestic companies in small towns.

February 2019

Accepted in Entrepreneurship \& Regional Development 


\section{Introduction}

Innovative companies search for ideas and knowledge beyond their boundaries (Chesborough 2003; Huizingh 2011). The literature considers urban areas to be the most favourable environments for finding a variety of new inputs due to a great level of diversity and density of different actors, companies and institutions. In this perspective, geographical proximity to other actors fosters rapid and easy knowledge exchange within urban areas and creates a so-called 'local buzz'. The lack of this variety and density of people, companies and knowledge institutions in small towns makes it necessary for companies to search for new knowledge beyond their locations. Fitjar and Rodríguez-Pose (2011), as well as Grillitsch and Nilsson (2015), show that innovative companies in small towns access external knowledge, meaning knowledge that is not inherent within their companies’ boundaries, through different non-local sources.

The aim of this article is to extend the literature on the ways companies in small towns access knowledge. The focus lies on the obstacles and opportunities that companies face when they access external knowledge sources due to their location in small towns. As Tödtling and Trippl $(2016,151)$ claim, local characteristics influence the knowledge accessing process:

"They [companies] face different challenges sourcing and acquiring such knowledge depending on their location. Also, the potential to get access to and combine different knowledge bases varies between metropolitan, specialized industrial and organizationally 'thin' contexts.”

Shearmur and Doloreux (2016) show that companies in non-core regions use infrequent interactions and non-market-sourced information, such as universities, more often, whereas companies in core regions more often use frequent interactions and marketsourced information, such as consultants. Hence, companies in different environments may be more likely to access certain knowledge sources than others. While the literature 
acknowledges the importance of external knowledge and the influence of local characteristics on the innovation process, there is little research explaining which local characteristics influence companies’ ability to access external knowledge. For this reason, companies located in small towns ${ }^{1}$ in the eastern part of Switzerland were chosen as a suitable unit of analysis.

These small towns function as central places outside core-regions, and they provide basic supplies, education and health services and have good transportation connections to core regions (Christaller 1933). Natural amenity-rich environments and good transportation connections to core regions may attract highly educated employees that bring along knowledge and networks to companies located in non-core regions (Keeble and Tyler 1995; Mayer, Habersetzer, and Meili 2016; Moss 2006). Thus far, the literature on economic development, and on innovation in particular, has ignored the category of small towns (Bell and Jayne 2009). Yet, small towns boast a specific environment that has advantages and disadvantages. A thin labour market, the presence of a limited amount of companies and the absence of research institutions result in a local environment where companies have few opportunities to obtain new ideas and knowledge. Nevertheless, companies in the small towns investigated are not located in the absolute periphery. Instead, they are in the midst of a so-called medium-interaction environment. This means that while companies do not have immediate access to innovation partners, they do have easy access to non-local factors of innovation (Shearmur 2012). Moreover, the small town context does indeed offer certain opportunities to companies that a more remote location, such as the rural countryside,

\footnotetext{
${ }^{1}$ To be defined as a town in Switzerland a settlement must have a density of inhabitants, jobs or equivalent for overnight stays, whose sum is higher than 500 per $\mathrm{km} 2$ in a grid cell with an edge length of 300 meters (see Goebel and Kohler (2014) for more information on the definition).
} 
may not offer. The small town as a specific type of location represents a specific local context for companies that so far has not been considered in the literature on innovation. Consequently, in this article the difference between small towns and more remote villages is acknowledged when innovation outside core regions is discussed. The urbanrural dichotomy in the innovation literature seems too general to provide an appropriate understanding of the different obstacles and opportunities that companies face when accessing knowledge beyond core regions.

Moreover, research shows that specific company characteristics influence how local obstacles or opportunities are experienced and which knowledge sources are accessed (Aslesen and Freel 2012; Fitjar and Rodríguez-Pose 2011; Grillitsch and Nilsson 2015, 2017; Malecki and Poehling 1999). In order to control for firm characteristics, the question how multinational companies (MNCs) in the high-tech industry are affected by small town characteristics when accessing external knowledge is investigated. MNCs in the high-tech industry were chosen for this study because small towns in Switzerland seem to persist as the locations of multinational high-tech companies, in this age of globalization and outsourcing.

MNCs perceive obstacles to innovation in their geographical location as less relevant than single domestic companies (SDCs) do (Iammarino, Sanna-Randaccio, and Savona 2009). This is because their subsidiaries in other locations can access local knowledge and transfer it to headquarters and the company's global network (Cantwell and Iammarino 2003; Mattes 2016). Hence, MNCs have other opportunities to compensate for the lack of local knowledge in their hometowns than SDCs (Regnér and Zander 2011). The literature on knowledge accessing beyond core regions only marginally discusses how companies’ global scopes affect the kind of non-local knowledge used and if these companies face different constraints or opportunities in 
small towns. Differentiating between multinational and national companies when analysing non-local sources of knowledge seems to be crucial for understanding innovation mechanisms, particularly when the focus lies on these dynamics in non-core regions.

To extend the existing literature on this issue, the two aspects - location characteristics and firm characteristics - that have so far mostly been discussed separately in the literature on external knowledge sources are combined and a multiple case study with five multinational high-tech companies with headquarters and R\&D departments in small towns in Switzerland is conducted. For the theoretical replication, two single domestic high-tech companies in Switzerland are investigated. This approach allows to obtain a higher external validity and to test if small town characteristics affect the extent to which multinational and domestic companies access knowledge. The following research questions drive the multiple case study: Which small town characteristics represent opportunities or obstacles for multinational high-tech companies when accessing which kind of external knowledge sources?

Bearing this research question in mind, the next section summarises the literature on knowledge accessing beyond core regions, small towns and MNCs. Afterwards, the research approach is introduced and the multiple case study is outlined. This section is followed by the results, which focus on the location characteristics that affect high-tech companies’ knowledge accessing and the difference between MNCs and SDCs. Finally, the findings are summarized and conclusions are drawn.

\section{Literature review}

A number of economic geographers show that, although there are fewer innovative companies in less urbanized regions, innovation occurs in small towns and is not only a result of inter-company competencies, but also of linkages to external 
knowledge sources (Aslesen and Isaksen 1998; Fitjar and Rodríguez-Pose 2011;

Grillitsch and Nilsson 2015; Keeble and Tyler 1995; Lee and Rodríguez-Pose 2013;

Shearmur and Doloreux 2016). However, the lack of 'local buzz' in small towns makes it necessary for companies to look beyond their local and regional borders in order to find new ideas and knowledge outside their local environment (Bathelt, Malmberg, and Maskell 2004). Empirical evidence shows that innovative companies in non-core regions have a higher probability of using international knowledge sources and are more likely to participate in national and international collaborations than their counterparts in core regions (Grillitsch and Nilsson 2015; Lorentzen 2007; Teirlinck and Spithoven 2008; Tödtling, Grillitsch, and Höglinger 2012). Capello (2017) distinguishes between different territorial patterns of innovation on the level of endogenous potential and linkages to external partners. Besides the endogenous innovation pattern, which draws on local conditions for the creation of knowledge, the creative application pattern relies on creative actors who search for knowledge outside the local environment and apply it locally to innovation needs. Cappello’s argument also supports Grillitsch and Nilsson’s (2015) conclusion that collaboration and networks allow innovative companies in noncore regions to compensate for the lack of local knowledge spillovers.

\section{External knowledge sources}

There is a broad range of external knowledge sources. Trippl $(2009,448)$ created the category of formal/traded relations and informal/untraded relations, which can either transfer knowledge or foster collective learning:

- Formal/traded relations for transferring knowledge: contract research, consulting, licenses, buying intermediate goods

- Formal/traded relations for collective learning: R\&D collaborations, shared use of R\&D facilities

- Informal/untraded relations for transferring knowledge: recruitment of specialists, 
monitoring competitors, participating in fairs and conferences, reading scientific literature and patent specifications

- Informal/untraded relations for collective learning: informal contacts

Especially informal knowledge linkages, such as monitoring competitors or recruiting specialists, that require only little investments and provide easy accessible knowledge, are more relevant for companies than formal networks or linkages to markets (Trippl 2009).

From a geographical perspective, Lorentzen (2007) discussed the frequency of the different non-local knowledge sources used. Lorentzen found that customers and media are the two most often used sources by low- and medium tech companies in the periphery of Poland. Shearmur and Doloreux (2016) note that companies in non-core regions more often make use of non-market-sourced information (universities, community colleges, government-run laboratories, conferences, fairs and the Internet), and they thus call them 'slow innovators'. In contrast, companies in core regions more often require frequent interactions and market-sourced information (clients, suppliers, consultants, commercial laboratories and research institutions).

To understand external knowledge sourcing mechanisms, not only knowledge about the kind of external knowledge sources is essential, but also about the ways how companies access this knowledge. External knowledge sourcing works over large distances because not all innovations require constant face-to-face interactions between innovation partners. As a result, other forms of proximity can substitute geographical proximity for certain kinds of innovations (McCann 2007; Tödtling and Grillitsch 2014; Trippl 2009). Torre (2008) argues that geographical proximity is only necessary during certain stages of the innovation process and that mobility can temporarily organize and create geographical proximity. Relationships and networks developed in previous 
employments might be important for the relative proximity to extra-regional knowledge sources. Agrawal et al. (2006) and Nilsson and Mattes (2013) support this argument by stating that social relationships that have been developed through geographical proximity are resilient against longer geographical distances and facilitate knowledge flows over large distances.

Relationship between firm characteristics and external knowledge used

Generally, in-house capabilities, knowledge intensity, knowledge base, the attitudes and values of managers and the company's age and size influence access and acquisition of external knowledge (Aslesen and Freel 2012; Fitjar and Rodríguez-Pose 2011; Grillitsch and Nilsson 2015, 2017; Malecki and Poehling 1999). Research also shows that industries that rely on slowly decaying technological information or analytical knowledge are less dependent on geographical proximity for the acquisition of new scientific knowledge, and they choose interlocutors that are mostly not local (Martin and Moodysson 2011; Morrison and Rabellotti 2009). Depending on a company's product lifecycle, as well as its knowledge base, it is more or less likely to engage in national or international knowledge exchange. Companies with a short product lifecycle and an analytical knowledge base (transformation of scientific knowledge) are most likely to engage in international collaborations, whereas companies with a long product lifecycle and synthetic knowledge base (application of existing knowledge, applied research) are least likely to work with extra-regional partners (Aslesen and Freel 2012; Herstad, Aslesen, and Ebersberger 2014). Hence, as these empirical results illustrate, small towns are not a default hostile environment for innovation - at least for certain innovations.

As research shows, the global reach of a company influences whether or not it 
perceives constraints to innovation in its environment (Iammarino et al. 2009). Studies mostly investigate the knowledge sourcing processes of companies outside core-regions without discussing their respective global scopes. Whether a company is multinational or not can influence its capability to access external sources of knowledge. Subsidiaries in different national contexts allow MNCs to more easily access knowledge from outside the seat of their headquarters and to access international innovation networks (Cantwell and Iammarino 2003; Iammarino and McCann 2015; Mattes 2016; Regnér and Zander 2011). Cantwell and Iammarino (2003) differentiate between three types of MNC innovation networks. The first type, the intra- company network, includes knowledge flows between parent company and its subsidiaries. The second type consists of the network between subsidiaries and indigenous companies. Lastly, the third type is a network with knowledge exchange between the parent company and other companies.

Research shows that knowledge exchange and innovation cooperation between subsidiaries and their headquarters is not an automatic process. MNCs tend to concentrate their main activities in one place and subsidiaries might only exchange knowledge within their boundaries, not with the rest of the company (Mattes 2016). Contrary to popular believe, MNCs are often reluctant to disperse their innovation activities and they develop most innovation projects at one location. Therefore, innovation in MNCs remains bound in space, as Mattes $(2016,408)$ concludes:

"the co-location of critical activities remains a driving factor, it facilities interaction and it helps to maintain control. On the other hand, the dispersed configuration of the MNC itself, with subsidiaries spread across various countries, means that there exist possibilities to draw upon knowledge from all over the world (...). This means that MNCs are not in all respect as global as we tend to think.” 
Nevertheless, subsidiaries embed MNCs in different institutional and business environments and hence make them 'neither completely footloose nor completely embedded companies' (Heidenreich et al. 2012, 2). If a MNC decides to disperse its innovation activities among its subsidiaries and counts with appropriate strategies for knowledge exchange, it has the opportunity to obtain knowledge from different places (Heidenreich et al. 2012). However, even if a company does not disperse its innovation projects, it still depends on, and can benefit from, its intra-company network as a source of learning. Organizational proximity is, however, an important precondition for a wellfunctioning network among different subsidiaries (Aslesen, Hydle, and Wallevik 2017).

These results reveal that MNCs have other opportunities available when compared with SDCs. Therefore, it is not surprising that MNCs perceive obstacles to external knowledge sourcing to be less significant than SDCs and are thus also less sensitive to their local context (Iammarino et al. 2009). By combining the literature on innovation beyond core regions and the literature on MNCs, this article assumes that a small town context affects MNCs differently than SDCs when accessing external knowledge sources. Hence, the empirical analysis focuses on the question if MNCs face different obstacles and opportunities in small towns compared to SDCs.

\section{Small town characteristics}

We know little about the ways in which characteristics of small towns may foster or hinder companies’ external knowledge sourcing process. Most studies that analyse innovation processes outside core regions focus on the type and amount of external knowledge sources that companies use but neglect the obstacles or opportunities that companies face while attempting to access these sources. Moreover, they do not differentiate between different types of locations outside core regions. The specific characteristics of locations, as well as their distance to core regions, can 
influence how companies are able to access external knowledge and how they can use other local companies or institutions as cooperation partners (Capello 2017; Shearmur 2012; Tödtling and Trippl 2016; Trippl, Grillitsch, and Isaksen 2017). Therefore, this article not only analyses which external knowledge sources companies use, but also focuses on how the context of small towns as medium-interactive environments affect companies’ access to external knowledge sources. Medium-interactive environments represent a specific local context for companies. Such an environment provides good access to core areas but lacks a 'local buzz' (Bathelt, Malmberg, and Maskell 2004). The missing co-location of companies and research institutions makes casual encounters that might lead to serendipitous knowledge exchange mostly impossible. Hence, short travel times to other places and communication with new technologies are necessary to access new knowledge. As Shearmur $(2012,121)$ suggests, 'the location of a region relative to other regions is a key determinant of employment, population and income growth (and, I suggest, of innovation dynamics) irrespective of other factors'. When we consider small towns as medium-interactive environments, we need to be aware that these locations are neither totally peripheral nor highly urbanized. Small towns differ from highly urbanized places that host a large and diverse range of innovation partners. However, they do offer easy access to non-local factors of innovation (Shearmur 2012). As a result, they represent a category that the literature rarely discusses, particularly in innovation studies (Bell and Jayne 2009). Small towns with good connections to core areas may be able to attract commuters and 'borrow' functions and performance from neighbouring cities, thereby compensating for their size (Alonso 1973; Meijers and Burger 2015). Empirical evidence shows that the relative distance to other cities or towns influences the flows of people between small towns and bigger cities (Sýkora and Mulíček 2017). In fact, the mobility of labour is seen as one important carrier of 
knowledge between regions (Tödtling and Trippl 2016). Accordingly, the missing 'local buzz' may be less important for locations that are easily accessible than for more remote locations (Shearmur 2012). However, geographical proximity to a core region itself is not the only benefit of a small town. Economic, cultural or social networks that connect different institutions and actors can also provide small towns with access to different functions and assets and may help companies to access external knowledge (Camagni, Capello, and Caragliu 2015; McCann and Acs 2011; Phelps, Fallon, and Williams 2001; Shearmur 2012). Small towns are not a default hostile environment for innovation - at least for certain innovations. Indeed, an overflow of external partners - as may occur in urban regions - can even make companies less innovative, since they may no longer be able to identify and absorb crucial information (Laursen and Salter 2006).

However, the labour market in small towns is rather thin, therefore small towns - also the ones in a medium-interaction environment - are less attractive to young and well-educated people since there are fewer opportunities for occupational progression (Gordon 2015). Accordingly, the lack of skilled personnel and the cost of innovating are some of the most important barriers to innovation for most companies (Galia and Legros 2004; Madrid-Guijarro, Garcia, and Van Auken 2009). Additionally, the lower availability of financial capital in small towns may influence companies’ financial opportunities, and their ability to access non-local knowledge sources (Cowling 1998).

To sum up, the literature shows that firm and location characteristics influence which kind of external knowledge is accessed. However, these two factors have so far not been combined in one study. This article is interested in how small town characteristics affect multinational high-tech companies when they access the external knowledge sources. To gain a higher validity of the results the results are compared 
with the help of a theoretical replication with two single domestic high-tech companies in small town in the same region.

\section{Research setting and method}

To understand how a small town context affects Swiss multinational high-tech companies that access external knowledge, a multiple case study design is applied (Yin 2009). In addition to the literal replication of five MNCs, a theoretical replication with two companies located within the same regional context but without international subsidiaries is conducted. This method increases the external validity of the study and allows to observe how a company’s specific characteristics - in this case its global scope - influence how it experiences obstacles or opportunities when accessing external knowledge.

The study area includes the small towns of Herisau, Flawil, Uzwil, Romanshorn and Frauenfeld in the eastern part of Switzerland that lie between $40 \mathrm{~km}$ and $80 \mathrm{~km}$ from Zurich (see Figure 1). This article defines small towns as towns that have between 5000 and 25000 inhabitants. The small towns in this study area are in the agglomeration around the city of St. Gallen (75 538 inhabitants), and they ranged in size from 9214 to 24864 residents in 2015 (BFS 2017). The periurban-rural region that embeds these small towns is a medium-interaction environment with good access to core regions in Switzerland and Europe but without immediate access to local innovation partners. Universities that specialise in technical sciences (particularly engineering) are absent in this part of Switzerland.

This region has a long industrial history. The textile industry emerged around the 1860s and the machine industry developed alongside it as its major suppliers. While the textile industry significantly declined and almost disappeared, some of the suppliers in the machine industry could diversify their products and became important in their 
respective niches. Today, approximately one third of employees in the eastern part of Switzerland work in the secondary sector, two thirds in the tertiary sector and less than ten percent in the primary sector (BFS 2015). The 2008 location coefficients show that the high-tech industry predominantly resides outside of Swiss core regions, such as Zurich or Geneva, in the eastern part of Switzerland close to the Lake Constance and in the western part of Switzerland in the Jura region (BFS 2008).

\section{[insert Figure 1 here]}

This regional context was primarily chosen due to the presence of a number of multinational high-tech companies in small towns. For this study, high-tech companies are the units of analysis. The high-tech industry is defined according to its technology intensity $^{2}$, which is calculated as R\&D expenditure relative to value added (Eurostat 2016). Among high-tech companies in the eastern part of Switzerland, MNCs were selected that have their headquarters in small towns. Most of these companies have a long history in their hometowns (20 years or more). By focusing on companies that have been in small towns for a longer time, also reasons for why these companies persistently remain in small towns in the current age of globalization and outsourcing can be found. Moreover, by focusing on older companies the certainty that the companies in question had to obtain new knowledge in order to further develop their products over the years is high. Therefore, they have experience in how the context of small towns affects them when accessing external knowledge. Companies may only

\footnotetext{
${ }^{2}$ High-technology includes the manufacturing of basic pharmaceutical products and preparations and the manufacturing of computer, electronic and optional products.

High-medium technology includes the manufacturing of chemicals and chemical products, the manufacturing of electrical equipment, the manufacturing of machinery and equipment, the manufacturing of motor vehicles, trailers and semi-trailers, and the manufacturing of other transport equipment
} 
recognize the advantages and disadvantages of their locations when they meet them during their activities (Galia and Legros 2004).

Five companies in four different small towns comply with these criteria and were willing to participate in this study. For the theoretical replication, two high-tech companies that also export their products worldwide, but which only have one national location for production and development, were selected. These two cases allow to test and compare the results obtained from the MNCs (Yin 2009).

Table 1 provides an overview of the companies and the interview partners. Table A1 in the Appendix lists the participants and the durations of the interviews in more detail. In total, 28 semi-structured interviews were conducted. In contrast to traditional studies on companies, three to six in-depth interviews for each company were conducted. To understand how a small town context affects companies, different people with different functions were interviewed. The initial request for company participation and the subsequent first interview with the companies' point of contact helped to access important people in the companies. This way, CEOs, innovation managers, production managers and human resource managers were consulted. Additionally, a set of interviews with public officials from the small towns were conducted to ensure that insights into companies’ development context is obtained. Hence, directors of industry organizations and local authorities that are responsible for companies in these towns were also interviewed. The interviews lasted from 14 to 84 minutes and were conducted between February and June 2017. The interview recordings were fully transcribed and analysed using the MAXQDA software, using codes to categorise the data. Company brochures, webpages and corporate reports were consulted to prepare the interview questions and to crosscheck the information that the interviewees provide. Data 
triangulation was ensured through interviews with different key people in the companies and the document analyses.

\author{
[insert Table 1 here]
}

\title{
Results
}

The overarching result of our study is that MNCs and SDCs in small towns do not source external knowledge from their local environment but develop linkages to external knowledge sources, as this has already been claimed by other authors before (e.g. Fitjar and Rodríguez-Pose 2011; Grillitsch and Nilsson 2015).

In fact, MNCs, as well as SDCs, actively obtain new knowledge and information outside their towns or region. All interviewees state that they are very much aware of the importance of non-local contacts, particularly in terms of the development of international innovation-, production- and sales networks, as the following quote illustrates:

'From the beginning, we could not rely on local or regional markets or partners we always had to go beyond local borders.' (Company 3, Interviewee 11)

The majority of the innovation activities of the MNCs interviewed occur at their headquarters, as this quote illustrates:

'It happens that a subsidiary from China sends us a drawing after they have talked to a client. Here at the headquarter, three people look at it and either say "that won’t work" or "it will be too expensive". We do not have this ability at subsidiaries worldwide.' (Company 3, Interviewee 18)

This finding supports Heidenreich et al.’s (2012) conclusion that companies concentrate their innovation activities at certain locations. The analysis of the interview data reveals that MNCs in small towns use four main sources of external-knowledge: 1) client’s feedback, 2) recruitment of new national and international employees, 3) 
research institutions and universities, 4) fairs, conferences and workshops. These sources are either formal and traded (source 3) or informal and untraded (1, 2 and 4) (Trippl 2009). Informal knowledge, which is more easily accessible, seems more relevant for companies in small towns. There seems not to be a difference between companies in big cities, such as Vienna where Trippl (2009) conducted the study and the small towns investigated in this study. Moreover, by using knowledge and information from market sources, such as clients, as well as non-market sources, such as universities, the MNCs have characteristics of so-called fast innovators, which confirms the results of Shearmur and Doloreux (2016). The results of the theoretical replication show that SDCs mention the same main sources of external knowledge, except for client feedback. All of the companies interviewed have clients spanning the globe. Accordingly, they would also have to design strategies to acquire client feedback over long distances when located in a core region. However, the results show that MNCs have less trouble accessing feedback from their clients due to their subsidiaries’ geographic proximity to them. A company located in a core region does probably not possess other strategies for acquiring information from clients. Concerning the companies' exchange with clients, the results support Shearmur's (2010) results that conclude that accessibility does not matter to high-tech companies. Hence, the small town context does not seem relevant in this regard and this aspect will therefore not be discussed further.

For the remaining three external knowledge sources, the MNCs and SDCs interviewed highlight two small town characteristics that provide opportunities for accessing external knowledge, namely natural amenities and rapid transportation connections. The rapid transportation connections are typical for towns located in medium-interactive environments and might not be inherent to more peripheral small 
towns. The companies also mention two obstacles, namely, missing agglomeration economies and the distance to the core city. Evidently, natural amenities and the absence of agglomeration economies differ from each other since natural amenities often require the absence of agglomeration economies. Hence, the results show that an opportunity can also be an obstacle for different sources of access to non-local knowledge. Furthermore, rapid transportation connections to the core city make it possible for companies to access certain external knowledge sources, however the results also show that the distance to the core can still be an obstacle for accessing some knowledge sources.

\section{Natural amenities versus absence of agglomeration economies}

Natural amenities in small towns, and the absence of agglomeration economies, are especially important for accessing knowledge from new employees. Local environment characteristics help persuade certain kinds of employees to move to a given region. Natural amenities and lower costs of living are especially attractive to employees older than 30 or employees with children. As one interviewee says:

'You have space, you have air to breath, you easily find living space. We live close to the wood where you can go for a run. We are in the country but still connected with the world.' (Company 1, Interviewee 23)

Currently, the literature on natural amenities concentrates on tourism towns or residential economy towns (Segessemann and Crevoisier 2015; Moss 2006). There is no research on the potential of natural amenities to attract highly qualified employees to high-tech industries. Despite this gap in knowledge, natural amenities can be a location advantage, and they may motivate qualified individuals to work in a company located in a small town. Additionally, the fact that the small towns in which the companies are 
located are not in the absolute periphery and have good infrastructures facilitates the search for non-local employees:

'The town is nice (...). There is a harbour area with a pedestrian area with restaurants, which is important. I think, if we were in a smaller village with only a small restaurant and nothing else, it would not seem very professional. I think that is the difference between a town and a village or even a green field. The green field does not create positive associations, but our town does.'(Company 6, Interviewee 2)

This quote sums up the importance of thinking about the 'periphery' differently. Smaller towns provide an environment that includes urban features, such as the presence of restaurants and cultural activities, as well as rural features, such as proximity to untouched nature or farming land. Together, these characteristics evolve into a special work and innovation environment that is significantly different from that of core regions or the absolute periphery.

However, the lack of urban amenities, such as a dense job market, universities or an urban atmosphere, makes it difficult for these companies to attract a freshly graduated work force to the small towns. New graduates with degrees from universities in core cities mostly do not prefer to work in the eastern part of Switzerland straight away, even if they grew up there:

'Our young people go to Zurich and do not come back. We have a real problem, and it is a challenge' (Company 9, Interviewee 2).

MNCs are able to ease this problem through intra-company transfers. This means transferring employees from a subsidiary to the headquarters for a given period of time, as the following quote shows: 
'I believe that our international orientation is very important. We have 26

locations in 15 different countries and we have an active exchange and people

from other subsidiaries come to our headquarter.' (Company 1, Interviewee 20)

Intracompany transfers are one way to bring new knowledge to companies in small towns, and it is a way that the literature on innovation outside core-regions does not mention. Cantwell and Iammarino (2003) mention that intra-firm networks are a type of innovation network available to MNCs. This type of innovation network may be especially important for MNCs in small towns, which are able to bring new employees from outside the region to the headquarters to work as creative actors. The results from the theoretical replication show that SDCs do not mention intra-company transfers as a way of finding new employees because they do not have subsidiaries. This suggests that MNCs are better able to react to labour shortages than SDCs due to established international intra-company networks and experience with subsidiaries abroad. Therefore, the assumption that the global scope of a company influences how companies are able to access non-local knowledge in a small town context is verified. Moreover, operating on a global scale helps to attract employees who wish to work in a global environment. Regarding the theoretical replication, these two strategies are the only advantages MNCs have compared with SDCs. So far, the literature does not mention the fact that the global orientation of companies outside core regions may attract employees to small towns and may even foster innovation activities.

Good transportation connections versus distance to core city Good transportation connections to the core city help to make small towns attractive as a work place for the employees and make it possible to reach partners at universities, as well as workshops and conferences, in Switzerland in a bearable amount of time. Since labour mobility is seen as one important carrier of knowledge between regions 
(Tödtlinge and Trippl 2016), this study also shows that relative proximity to bigger cities is an asset for accessing external knowledge. Moreover, rapid transportation connections to core regions and natural amenities together with modern company infrastructures drive decisions to locate workshops in small towns:

'People also like to come to us. We have a nice laboratory and nice venues for meetings. We have committee meetings that are normally in Bern or Zurich. They like to come to us from time to time’ (Company 6, Interviewee 4)

Being well-known in the industry as a reliable cooperation partner also encourages partners to work with companies located in small towns. It does not matter if the company is multinational or not. Attracting different actors to small towns can temporarily create a 'local buzz’ (Bathelt, Malmberg, and Maskell 2004).

The mental distance to the core region seems to be a greater problem than the physical distance (Boschma 2005). The absence of technological universities in the eastern part of Switzerland and the feeling of 'not belonging to the core region' makes cooperation with, for example the ETH in Zurich, one of the leading technical universities worldwide, uncommon, as one interviewee tells us:

'You always have to travel, and everyone says, “ah, he was at the ETH again!” It is nearly like a ceremonial act.' (Company 1, Interviewee 20)

The approximately one-hour train ride from these small towns to Zurich does probably not hinder companies from cooperating with the ETH. However, company culture and the mental distance to universities might outweigh the physical distance. To establish cooperation with universities or research institutions, the managers of the companies, as well as the employees, must be open to cooperation. Although many of the companies interviewed work with universities or technical colleges, two people from different 
companies in the same town said that the individualistic attitude regarding technical problems is in the DNA of the company.

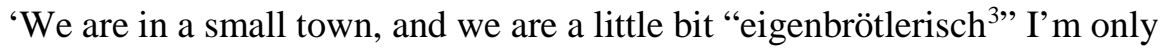
allowed to spend a small amount of the operation output for external development. I have to justify myself every time for external cooperation.' (Company 4, Interviewee 7)

This result shows that some companies in small towns have a rather introverted position regarding external knowledge (Malecki and Poehling 1999). This supports Fitjar and Rodríguez-Pose’s (2011) results that the open-mindedness and attitude of managers influence the range of cooperation activities, even though in some cases like the quote suggests they may structurally be constrained. However, there is still the question of how a small town context influences the culture in companies in regard to external cooperation. Notwithstanding, any differences between MNCs and SDCs in regard to collaborations with universities and colleges cannot be identified. The reason for this could be that the R\&D departments that are responsible for collaborations reside in small towns and not abroad.

The distance to the core city is not a problem for pre-arranged meetings. However, despite the good transportation connections, the distance seems too far for spontaneous exchanges or meetings or for the use of rapid innovation sources (Shearmur and Doloreux 2016).

'If I want to go to a seminar or speech for example in Zurich, then it takes at least half a day. I have to take the train or the car to go there, be there, and travel back. Then you think about it twice, if you want to do that.' (Company 6, Interviewee 5)

\footnotetext{
${ }^{3}$ Meaning: individualistic
} 
Employees' willingness to be mobile is crucial for companies in small towns. To attend fairs, conferences and workshops, companies must motivate their employees to travel (Torre 2008). Concerning Capello’s (2017) creative application pattern, companies in small towns are highly dependent on employees who want to go beyond the local environment and acquire knowledge from participation in fairs, conferences and workshops. However, other than the study conducted by Fitjar and Rodríguez-Pose (2011), which discusses the importance of the open-mindedness of managers, the literature on external knowledge sourcing does not investigate the willingness of employees to travel to acquire knowledge. In future studies, the focus must lie more on the characteristics that economic actors have in non-core regions since they may influence if and how non-local sources of knowledge are used.

\section{Conclusion}

Both firm and location characteristics influence the types of knowledge sources companies use. These two factors have been discussed - albeit independently - in the recent literature interested in the use of external knowledge. However, to understand the difficulties or also opportunities certain companies face in certain places when accessing external knowledge, these two factors need to be combined. This study investigated how small town characteristics influence multinational high-tech companies when accessing external knowledge sources.

Small towns are special because they represent a spatial type that is positioned between the core and rural regions and their characteristics have rarely been discussed in the literature on innovation. They represent medium interactive environments that have quite a bit to offer to companies and their innovation processes. Additionally, MNCs are not as footloose as assumed and indeed depend on the local context they are embedded in. This is especially relevant for countries like Switzerland or Germany because small 
towns are often the location of MNCs (BBSR 2018). Studies so far have overseen their innovation processes and how small town characteristics shape those. By adopting a comparative approach (MNCs vs. SDCs), we are able to contribute to a much deeper understanding about why such companies are successful and how local circumstances support or hinder them in being innovative.

This study leads to two main results that extend the literature on innovation beyond core regions and gives - while there are for sure many others - some explanations why MNCs persistently remain in small towns:

1. The characteristics of small towns as medium-interactive environments are not per se an opportunity or obstacle for accessing external knowledge. Depending on the type of knowledge companies want to acquire, local characteristics can be an obstacle or opportunity. Some characteristics that are normally seen as disadvantage, such as the lack of agglomeration economies, can turn into an advantage. Natural amenities can for example attract certain employees or be a reason to hold conferences in small towns. Fast transportation connections to core cities facilitate scheduled meetings. However, the travel time is still too long for spontaneous meetings or visits. As this study as well as previous studies confirm, small town companies with strong in-house capabilities do not seem to have difficulties in accessing strategically external knowledge they need (Grillitsch \& Nilsson 2015, 2017). Hence, it is not for every company necessary to be in an urban core to be successful. In addition, firms in city regions also do not seem to benefit from 'just being there' in terms of relationships conducive to innovation (Fitjar and Rodríguez-Pose 2017).

2. Whether a high-tech company is multinational or not does not influence much how small town characteristics are perceived for acquiring innovation relevant 
information. In comparison to domestic companies, the interviewed MNCs are more flexible in bringing international employees to their headquarters due to inter-company transfers. Otherwise, the theoretical replication with two SDCs did not show noteworthy differences. As Heidenreich et al. (2012) already show, this is due to the concentration of the most important innovation activities at company headquarters and not at globally distributed subsidiaries. When accessing client feedback, a multinational orientation plays a role due to its globally distributed subsidiaries. However, the small town context does not matter in that respect. With these results, a better understanding how companies' global scopes affect external knowledge sourcing processes in small towns can be gained. Previous studies that focus on innovation in non-core regions have neglected that aspect so far.

The interviews with a variety of actors in each company allowed to capture different perspectives inside each company and to appreciate the different facets of the process of knowledge acquisition. Five multinational high-tech companies in small towns in the eastern part of Switzerland are investigated. To gain more validity, these results are compared with two national high-tech companies in the same region. How companies finally transmit knowledge from their clients, universities or conferences to their headquarters as well as the difficulties they experience while acquiring it is an issue that goes beyond the scope of that article.

With these results, awareness should be raised that the core-periphery dichotomy that is dominant in the innovation literature is too rough and that - when talking about how the local context influences companies' ability to access external knowledge specific local characteristics should be considered. The literature is extended by starting to discuss specific local characteristics that hinder or support the external knowledge 
accessing processes. This can lead to a better understanding about the kinds of local factors that can play an important role in the innovativeness of companies.

In policy terms, the driving question is how small towns can support the innovativeness of MNCs and SDCs located in them. The companies in the small towns investigated are familiar with looking beyond the regional context to acquire knowledge. Encouraging companies to establish their networks abroad and to create an attractive living and working environment that is alluring to new employees and visitors may improve companies’ abilities to develop knowledge networks. Moreover, frequent and rapid transportation connections to core regions and airports are essential for facilitating occasional face-to-face meetings.

While this article analyses how small town characteristics affect access to the main external knowledge sources that companies use, it does not investigate whether or not companies fail to access certain external knowledge sources at all due to local circumstances. However, since it is only possible to see most obstacles or opportunities when companies access knowledge, it can be difficult for them to assess whether or not certain location characteristics would be problematic. Additionally, the case study draws on successful and exporting high-tech companies. Given that the high-tech industry is one of the most important industries in Switzerland, it is probable that this type of exportoriented industry is especially capable to access and generate knowledge. Companies that operate outside the export-oriented high-tech sectors may face other constraints in their innovation processes. Hence, future studies should analyse the location characteristics that may impede access to certain external knowledge sources and also focus on companies with different characteristics or sectors. Moreover, it would also be interesting to know how corporate culture and attitudes towards external knowledge are influenced by the local context. 


\section{Bibliography}

Alonso, William. 1973. “Urban Zero Population Growth.” Daedalus 102 (4): 191-206.

Aslesen, Heidi, and Arne Isaksen. 1998. "Innovation in Ultra-Peripheral Regions: The Case of Finnmark and Rural Areas in Norway.” STEP Rapportserien. Oslo.

Aslesen, Heidi, and Mark, Freel 2012. “Industrial Knowledge Bases as Drivers of Open Innovation?” Industry and Innovation 19 (7): 563-584. doi:10.1080/13662716.2012.726807

Aslesen, Heidi, Katja Maria, Hydle, and Kristin Wallevik. 2017. "Extra-regional Linkages through MNCs in Organizationally Thick and Specialized RISs : A Source of New Path Development ?” European Planning Studies 25 (3): 443-461. doi:10.1080/09654313.2016.1273322

Bathelt, Harald, Anders Malmberg, and Peter Maskell. 2004. "Clusters and Knowledge: Local Buzz, Global Pipelines and the Process of Knowledge Creation.” Progress in Human Geography 28 (1): 31-56. doi:10.1191/0309132504ph469oa.

BBSR. 2018. "Hidden Champions - Stabilisierungs- und Entwicklungsfaktoren von Kleinstädten in peripheren Lagen.” Kleinstädte in Deutschland - Urbanität. Vielfalt. Perspektiven. Accessed November 5 2018. http://www.laghavelland.de/wp-content/uploads/20180620-factsheet-hidden-champions.pdf.

Bell, David, and Mark Jayne. 2009. "Small Cities? Towards a Research Agenda.” International Journal of Urban and Regional Research 33 (3): 683-99. doi:10.1111/j.1468-2427.2009.00886.x.

BFS. 2008. “Betriebszählung.” Neuchâtel.

—_. 2015. “Beschäftigte nach den drei Wirtschaftsstektoren 2015.” Neuchâtel.

—. 2017. “Statistik der Bevölkerung und der Haushalte (STATPOP).” Neuchâtel. Boschma, Ron. 2005. "Proximity and Innovation: A Critical Assessment.” Regional Studies 39 (1): 61-74. doi:10.1080/0034340052000320887.

Camagni, Roberto. 1995. “The Concept of Innovative Milieu and its Relevance for Public Policies in European Lagging Regions.” Papers in Regional Science 74 (4): 317-40. doi:10.1111/j.1435-5597.1995.tb00644.x.

Camagni, Roberto, Roberta Capello, and Andrea Caragliu. 2015. “The Rise of SecondRank Cities: What Role for Agglomeration Economies?” European Planning Studies 23 (6): 1069-89. doi:10.1080/09654313.2014.904999. 
Cantwell, John, and Simona Iammarino. 2003. Multinational Corporations and European Regional Systems of Innovation. New York: Routledge. doi:10.4324/9780203986714.

Capello, Roberta. 2017. “Towards a New Conceptualization of Innovation in Space:

Territorial Patterns of Innovation.” International Journal of Urban and Regional Research 41 (6): 976-996. doi:10.1111/1468-2427.12556.

Chesborough, Henry. 2003. Open Innovation: The New Imperative for Creating and Profiting from Technology. Cambridge, MA: Harvard Business Press.

Christaller, Walter. 1933. Die Zentralen Orte in Süddeutschland: Eine ÖkonomischGeographische Untersuchung über die Gesetzmässigkeit der Verbreitung und Entwicklung der Siedlungen mit städtischen Funktionen. Jena: Gustav Fischer.

Cowling, Marc. 1998. "Regional Determinants of Small Firm Loans Under the U . K . Loan Guarantee Scheme.” Small Business Economics 11 (2): 155-67. doi:10.1023/A:1007956403565.

Eurostat. 2016. “High-Tech Industry and Knowledge-Intensive Services (Htec). Reference Metadata in Euro SDMX Metadata Structure (ESMS).” Accessed November 5 2018. https://ec.europa.eu/eurostat/cache/metadata/en/htec_esms.htm Fitjar, Rune Dahl, and Andrés Rodríguez-Pose. 2011a. "Innovating in the Periphery: Firms, Values and Innovation in Southwest Norway.” European Planning Studies 19 (4): 555-74. doi:10.1080/09654313.2011.548467.

Fitjar, Rune Dahl, and Andrés Rodríguez-Pose. 2017. "Nothing Is in the Air.” Growth and Change 48 (1): 22-39. doi: 10.1111/grow.12161.

Galia, Fabrice, and Diègo Legros. 2004. “Complementarities between Obstacles to Innovation: Evidence from France.” Research Policy 33(8): 1185-1199. doi:10.1016/j.respol.2004.06.004.

Goebel, Viktor, and Florian Kohler. 2014. Raum mit städtischem Charakter 2012. Erläuterungsbericht. Neuchâtel: Bundesamft für Statistik (BFS).

Gordon, Ian R. 2015. “Ambition, Human Capital Acquisition and the Metropolitan Escalator.” Regional Studies 49(6): 1042-1055. doi:10.1080/00343404.2013.799767.

Grillitsch, Markus, and Magnus Nilsson. 2015. “Innovation in Peripheral Regions: Do 
Collaborations Compensate for a Lack of Local Knowledge Spillovers?” Annals of Regional Science 54 (1): 299-321. doi:10.1007/s00168-014-0655-8.

Grillitsch, Markus, and Magnus Nilsson. 2017. "Firm Performance in the Periphery: On the Relation between Firm-Internal Knowledge and Local Knowledge Spillovers.” Regional Studies 51(8): 1219-1231. doi:10.1080/00343404.2016.1175554.

Heidenreich, Martin, Chrisoph Barmeyer, Knutt Koschatzky, Jannika Mattes, Elisabeth Baier, and Katharina Krüth. 2012. Multinational Enterprises and Innovation. Regional Learning Networks. Oxon: Routledge.

Herstad, Sverre J., Heidi Aslesen, and Bernd, Ebersberger. 2014. “On Industrial Knowledge Bases, Commercial Opportunities and Global Innovation Network Linkages.” Research Policy 43(3): 495-504. doi:10.1016/j.respol.2013.08.003.

Huizingh, Elko. 2011. “Open Innovation: State of the Art and Future Perspectives.” Technovation 31(1): 2-9. doi:10.1016/j.technovation.2010.10.002.

Iammarino, Simona, and Philip McCann. 2015. “Multinational Enterprises Innovation Networks and the Role of Cities.” In The Handbook of Global Science, Technology and Innovation, edited by Daniele Archibugi and Andrea Filippetti, 290-312. Oxford: Wiley-Blackwell. doi:10.1002/9781118739044.

Iammarino, Simona, Francesca, Sanna-Randaccio, and Maria Savona. 2009. “The Perception of Obstacles to Innovation . Foreign Multinationals and Domestic Firms in Italy.” Revue D’économie Industrielle 125(1): 75-104. doi:10.4000/rei.3953.

Keeble, David, and Peter Tyler. 1995. "Enterprising Behaviour and the Urban-Rural Shift.” Urban Studies 32 (6): 995-97. doi:10.1080/00420989550012753.

Laursen, Keld, and Ammon, Salter. 2006. “Open for Innovation: The Role of Openness in Explaining Innovation Performance among U.K. Manufacturing Firms.” Strategic Management Journal 27(2): 131-150. doi:10.1002/smj.507.

Lee, Neil, and Andres Rodríguez-Pose. 2013. “Original Innovation, Learnt Innovation and Cities: evidence from UK SMEs.” Urban Studies 50 (9): 1742-59. doi:10.1177/0042098012470395.

Lorentzen, Anne. 2007. “The Geography of Knowledge Sourcing-A Case Study of Polish Manufacturing Enterprises.” European Planning Studies 15 (4): 467-86. doi:10.1080/09654310601133252. 
Madrid-Guijarro, Antonia, Garcia, Domingo, and Howard Van Auken. 2009. “Barriers to Innovation among Spanish Manufacturing SMEs.” Journal of Small Business Management 47(4): 465-488. doi:10.1111/j.1540-627X.2009.00279.x.

Malecki, Edward J., and Ryan M. Poehling. 1999. “Extroverts and Introverst: Small Manufacturers and Their Information Sources.” Entrepreneurship \& Regional Development 11 (3): 247-68. doi:https://doi.org/10.1080/089856299283191.

Martin, Roman, and Jerker Moodysson. 2011. “Comparing Knowledge Bases: On the Geography and Organization of Knowledge Sourcing in the Regional Innovation System of Scania, Sweden.” European Urban and Regional Studies 20 (2): 17087. doi:10.1177/0969776411427326.

Mattes, Jannika. 2016. “The Geography of Innovation in Multinational Companies: Internal Distribution and External Embeddedness.” In Handbook on the Geographies of Innovation, edited by Richard Shearmur, Christophe Carrincazeaux, and David Doloreux, 399-413. Cheltenham: Edward Elgar Publishing Limited. doi:10.4337/9781784710774.

Mayer, Heike, Antoine Habersetzer, and Rahel Meili (2016). "Rural-Urban Linkages and Sustainable Regional Development: The Role of Entrepreneurs in Linking Peripheries and Centers. Sustainability 8(8). Doi:10.3390/su8080745.

McCann, Philip. 2007. "Sketching Out a Model of Innovation, Face-to-Face Interaction and Economic Geography.” Spatial Economic Analysis 2 (2): 117-34. doi:10.1080/17421770701346622.

McCann, Philip, and Zoltan J. Acs. 2011. “Globalization: Countries, Cities and Multinationals.” Regional Studies 45 (1): 17-32. doi:10.1080/00343404.2010.505915.

Meijers, Evert J., and Martijn J. Burger. 2015. "Stretching the Concept of ' Borrowed Size.”" Urban Studies 54 (1): 1-23. doi:10.1177/0042098015597642.

Morrison, Andrea, and Roberta Rabellotti. 2009. "Knowledge and Information Networks in an Italian Wine Cluster.” European Planning Studies 17 (7): 9831006. doi:10.1080/09654310902949265.

Moss, Laurence A.G. 2006. The Amenity Migrants. Seeking and Sustaining Mountains and Their Cultures. Wallingford: CABI Pub. doi:10.1079/9780851990842.0000. 
Phelps, Nicholas A., Robert J Fallon, and Corey Williams. 2001. "Small Firms, Borrowed Size and the Urban-Rural Shift.” Regional Studies 35 (7): 613-24. doi:10.1080/00343400120075885.

Regnér, Patrick, and Udo Zander. 2011. "Knowledge and Strategy Creation in Multinational Companies: Social-Identity Frames and Temporary Tension in Knowledge Combination.” Management International Review 51 (6): 821-50. doi:10.1007/s11575-011-0110-3.

Segessemann, Alain, and Olivier Crevoisier. 2016. "Beyond Economic Base Theory: The Role of the Residential Economy in Attracting Income to Swiss Regions.” Regional Studies 50 (8): 1388-1403. doi:10.1080/00343404.2015.1018882.

Shearmur, Richard. 2010. “Space, Place and Innovation: A Distance-Based Approach.” Canadian Geographer 54 (1): 46-67. doi:10.1111/j.1541-0064.2009.00302.x.

_ 2012. "Not Being There: Why Local Innovation Is Not (Always) Related to Local Factors.” In Foundations of the Knowledge Economy, edited by Knut Ingar Western, 117-38. Cheltenham: Edward Elgar Publishing Limited. doi:10.4337/9780857937711.00013.

Shearmur, Richard, and David Doloreux. 2016. "How Open Innovation Processes Vary between Urban and Remote Environments: Slow Innovators, Market-Sourced Information and Frequency of Interaction.” Entrepreneurship \& Regional Development 28 (5-6): 337-57. doi:10.1080/08985626.2016.1154984.

Sýkora, Luděk, and Ondřej Mulíček. 2017. "Territorial Arrangements of Small and Medium-Sized Towns from a Functional-Spatial Perspective.” Tijdschrift Voor Economische En Sociale Geografie 108 (4): 438-55. doi:10.1111/tesg.12249.

Teirlinck, Peter, and André Spithoven. 2008. “The Spatial Organization of Innovation: Open Innovation, External Knowledge Relations and Urban Structure.” Regional Studies 42 (5): 689-704. doi:10.1080/00343400701543694.

Tödtling, Franz, and Markus Grillitsch. 2014. “Types of Innovation, Competencies of Firms, and External Knowledge Sourcing-Findings from Selected Sectors and Regions of Europe.” Journal of the Knowledge Economy 5 (2): 330-56. doi:10.1007/s13132-012-0139-y.

Tödtling, Franz, Markus Grillitsch, and Christoph Höglinger. 2012. “Knowledge 
Sourcing and Innovation in Austrian ICT Companies - How Does Geography Matter?” Industry and Innovation 19 (4): 327-48.

doi:10.1080/13662716.2012.694678.

Tödtling, Franz, and Michaela Trippl. 2016. “How Do Firms Acquire Knoweldge in Different Sectoral and Regional Contexts?” In Handbook on the Geographies of Innovation, edited by Richard Shearmur, Christophe Carrincazeaux, and David Doloreux, 142-154. Cheltenham: Edward Elgar Publishing Limited. doi:10.4337/9781784710774.

Torre, André. 2008. “On the Role Played by Temporary Geographical Proximity in Knowledge Transmission.” Regional Studies 42 (6): 869-89. doi:10.1080/00343400801922814.

Trippl, Michaela. 2009. "Knowledge Sourcing Beyond Buzz and Software Sector.” Economic Geography 85 (4): 443-62. doi:10.1111/j.1944-8287.2009.01047.x. Trippl, Michaela, Grillitsch, Markus, and Arne Isaksen. 2017. Exogenous Sources of Regional Industrial Change: Attraction and Absorption of Non-Local Knowledge for New Path Development. Progress in Human Geography: 1-19. doi:10.1177/0309132517700982.

Yin, Robert K. 2009. Case Study Research. Design and Methods. 4thed. Thousand Oaks, CA: Sage Publications.

\section{Appendix}

[insert Table A1 here] 